\title{
Study of fetomaternal outcome in second stage caesarean section
}

\author{
Kamal D. Goswami, Manisha M. Parmar*, Avnika N. Kunjadiya
}

Department of Obstetrics and Gynecology, P.D.U. Medical College, Rajkot, Gujarat, India

Received: 26 March 2019

Accepted: 03 May 2019

\section{*Correspondence:}

Dr. Manisha M. Parmar,

E-mail: parmar.monisha88@gmail.com

Copyright: ( ) the author(s), publisher and licensee Medip Academy. This is an open-access article distributed under the terms of the Creative Commons Attribution Non-Commercial License, which permits unrestricted non-commercial use, distribution, and reproduction in any medium, provided the original work is properly cited.

\section{ABSTRACT}

Background: The incidence of second stage caesarean section is more in developing countries. Caesarean sections done at full cervical dilatation with impacted fetal head are difficult and associated with an increased incidence of maternal and fetal complications.

Methods: This was prospective observational study conducted at a tertiary teaching institute. All second stage caesarean sections performed between September 2017 to August 2018 were analysed in terms of incidence, indications of caesarean-section, intra-operative and postoperative complications, maternal and fetal outcome.

Results: During the study period there were total 7270 deliveries. Out of this 1884 deliveries were done by caesarean section. Out of them 50 were 2 nd stage caesarean sections contributing to $2.65 \%$ of total sections. Patwardhan method was used in $50 \%$ cases for deliveryof deeply engaged head. Intra-operative complications were higher in terms of atonic pph $(8 \%)$, extension of uterine incision $(16 \%)$, in 3 cases bladder injury was noticed. Obstetric hysterectomy was required in $4 \%$ cases. $14 \%$ cases had postoperative febrile illness and $8 \%$ cases had wound infection. $44 \%$ babies required NICU admissions and neonatal death was $18 \%$.

Conclusions: Caesarean section in the $2^{\text {nd }}$ stage of labour is associated with significantly increased maternal morbidity. Neonatal morbidity and mortality also increases. A proper judgement is required by a skilled obstetrician to take a decision for caesarean section at full cervical dilatation.

Keywords: Patwardhan method, Postpartum hemorrhage, Second stage caesarean section

\section{INTRODUCTION}

A caesarean section at second stage occurs when mother requires delivery at full dilatation of cervix, which poses a risk to mother and the fetus. The increasing trend of CS at second stage is of major concern in modern obstetrics. Incidence of second stage CS has increased from $0.9 \%$ to $2.2 \% .^{1}$ Second stage CS has been reported as a concerning increase trend within the increasing CS rate. ${ }^{1,2}$ Literature review suggests that this trend is multifactorial; probably a combination of lack of training for junior staff in second stage decision making, lack of expertise in assisted vaginal delivery. ${ }^{2}$ Increase in primary CS has a great impact on subsequent obstetric outcome and delivery. Royal College of Obstetricians and Gynaecologists (RCOG) reports that $6 \%$ of primary CS occurs at full dilatation and in $50 \%$ of these patients there was no attempt of instrumental vaginal delivery. ${ }^{3} \mathrm{CS}$ at full dilatation is a technically more challenging procedure than CS in early labour. ${ }^{4}$ There is also difficulty in delivery of deeply engaged head which can be delivered by Patwardhan method or by push method. The maternal morbidity is higher in second stage CS. ${ }^{2,5}$ Maternal morbidity in second stage CS is in the form of extension of uterine angles, postpartum haemorrhage and prolonged surgical time. ${ }^{6,7}$ Bladder injury, postpartum pyrexia were among the common complications reported during second stage CS. ${ }^{8,9}$ Neonatal morbidity in terms of NICU admissions, foetal academia, hypoxemia, prolonged 
NICU stay is reportedly higher in second stage CS. ${ }^{10,11}$ Decision making for CS in the second stage of labour is one of the greatest challenges in current obstetric practice. Involvement of a skilled obstetrician in the management of second stage CS aids in minimising the morbidity and mortality.

The objectives of this study were to determine the incidence of LSCS in second stage of labour, and the indications for LSCS in second stage of labour. Also, determined the fetomaternal outcome in second stage caesarean sections.

\section{METHODS}

This prospective observational study was carried out in the department of Obstetrics and Gynaecology of P.D.U Medical College, Rajkot for the period of one year from September 2017 to August 2018. During the study period all the lower segment caesarean sections performed in second stage of labour were included in the study. The data were collected in preformed proforma and written and informed consent was taken. Fifty women who underwent second stage CS were analysed in terms of indications for second stage CS, method of delivering the deeply engaged head, intra-operative and postoperative complications, as well as fetal outcome. Institutional ethical committee approval was obtained for the study.

\section{Inclusion criteria}

- All the second stage caesarean sections done at department of obstetrics and gynecology at P.D.U Medical, Rajkot.

\section{Exclusion criteria}

- Second stage caesarean sections done outside and referred to P.D.U Medical College for further management.

\section{RESULTS}

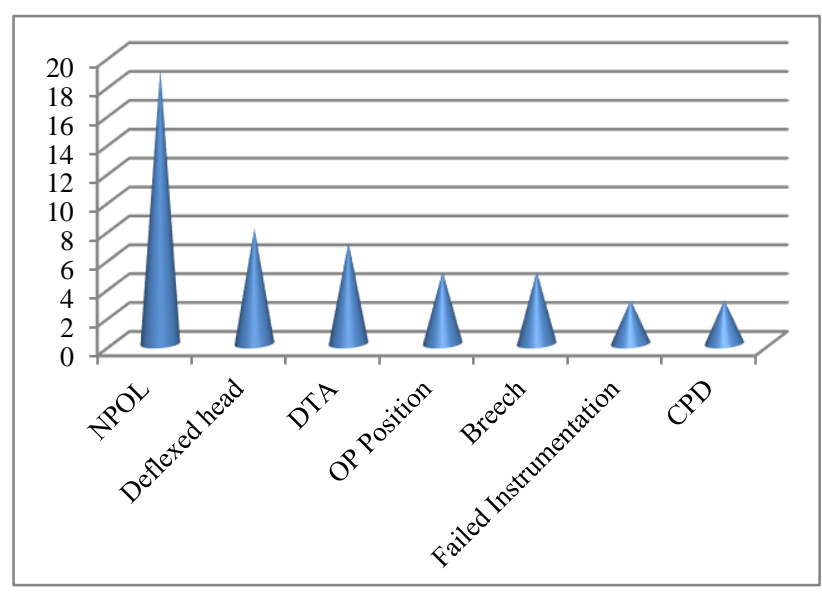

Figure 1: Indications of caesarean section in second stage of labour.
Total number of deliveries during the study period was 7270. Among these 1884 delivered by caesarean section. Out of this $50(2.65 \%)$ caesarean were performed in second stage. Non-progress of labour associated with fetal distress was the most common indication for LSCS in second stage of labour accounting for 19 cases $(38 \%)$ followed by deflexed head 8 cases (16\%) and deep transverse arrest 7 cases (14\%) (Figure 1).

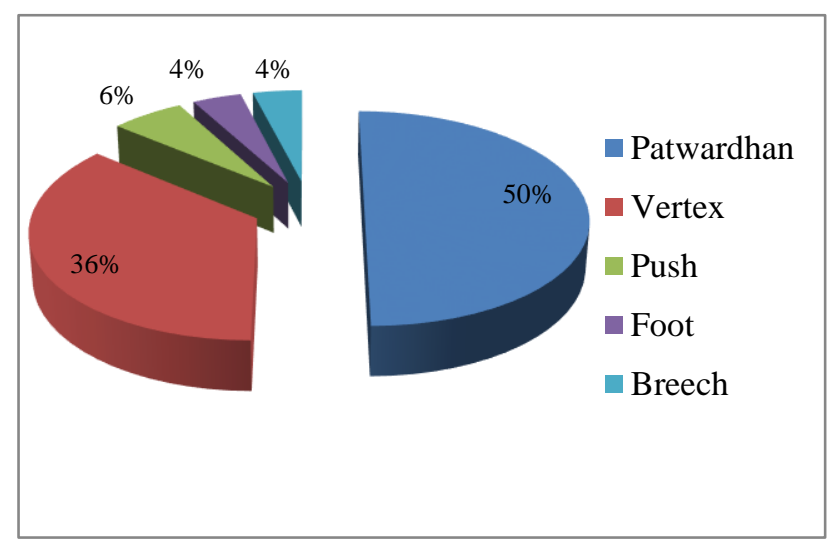

Figure 2: Technique of delivery of deeply engaged head.

Table 1: Intra-operative complications.

\begin{tabular}{|ll|}
\hline Intra-operative complications & No. (percentage) \\
\hline Extension of uterine angles & $8(16 \%)$ \\
\hline Atonic pph & $4(8 \%)$ \\
\hline Bladder injuries & $3(6 \%)$ \\
\hline Obstetric hysterectomy & $2(4 \%)$ \\
\hline
\end{tabular}

Most common method of delivery of deeply engaged head was Patwardhan method in 25 cases $(50 \%)$ followed by vertex method in $36 \%$ and push method in $6 \%$ (Figure 2). Intra-operative complications were extension of uterine angles 8 cases (16\%), atonic PPH 4 cases $(8 \%)$, bladder injuries 3 cases $(6 \%)$ and obstetric hysterectomy in 2 cases $(4 \%)$ (Table 1). Post-operative complications were paralytic ileus 7 cases (14\%), febrile illness 7 cases $(14 \%)$ and wound infection 4 cases $(8 \%)$ (Table 2).

Table 2: Post-operative complications.

\begin{tabular}{|ll|}
\hline Post-operative complications & No. (percentage) \\
\hline Paralytic ileus & $7(14 \%)$ \\
\hline Febrile illness & $7(14 \%)$ \\
\hline Wound infection & $4(8 \%)$ \\
\hline Hemorrhagic urine & $5(10 \%)$
\end{tabular}

Table 3: Fetal and newborn complications.

\begin{tabular}{|ll|}
\hline Complications & No. (percentage) \\
\hline Nicu admission & $22(44 \%)$ \\
\hline Fresh still birth & $5(10 \%)$ \\
\hline Neonatal death & $9(18 \%)$ \\
\hline
\end{tabular}


There were 22 babies (44\%) required NICU admissions, fresh still birth were $5(10 \%)$ and out of the 22 NICU admissions, neonatal death occurred in 9 cases $(18 \%)$ (Table 3).

\section{DISCUSSION}

During the one year study period 1884 babies were delivered by C-Section; of these $(n=50) 2.65 \% \quad C$ Sections were performed at full dilatation. Most common indications for $2^{\text {nd }}$ stage $\mathrm{C}$-section was non progress of labour with fetal distress followed by deflexed head and deep transverse arrest (DTA) (Figure 1). As the duration for second stage increases, there would be more difficulties due to oedematous lower segment, overstretched and thinned out lower segment and more impaction of presenting part in pelvis. Operative time was also increased due to difficulty of delivery of deeply engaged head. Delivery of deeply engaged head is challenge to obstetrician, this can be done by various methods as Vertex method, pull method i.e. Patwardhan's Method, push method in this method head is pushed vaginally and then head is delivered through uterine incision. In study group deeply engaged head delivered by Patwardhan method were $50 \%$, vertex method were $36 \%$ and by push method $6 \%$.

In this study, atonic PPH was observed in $8 \%$ of patients and extension of uterine incision was found $16 \%$ of patients. As compare to study conducted by Baloch $\mathrm{S}$ et al was observed $12.5 \% \mathrm{PPH}$ and $5.4 \%$ extension of wound. ${ }^{12}$ Increased incidence of atonic postpartum hemorrhage due to prolonged $2^{\text {nd }}$ stage of labour. Bladder injury was observed in 3 cases. Obstetric hysterectomy done in 2 cases. One hysterectomy done as patient referred late from lower health centre for prolonged second stage which ultimately resulted in ruptured uterus. Second hysterectomy done for post LSCS lower segment hematoma. Post-operative complications like febrile illness in $14 \%$ cases, paralytic ileus in $14 \%$ cases and wound infection in $8 \%$ were more in study group. Future VBAC chances are also reduced due to maternal morbidity associated with $2^{\text {nd }}$ stage C-Section. NICU admissions and neonatal deaths were significantly high due to birth asphyxia in study group.

\section{CONCLUSION}

Caesarean section in the second stage of labour is associated with significantly increased maternal and neonatal morbidity as well as increased neonatal mortality. A proper judgement and skilled obstetrician are required to perform second stage caesarean section.
Funding: No funding sources Conflict of interest: None declared

Ethical approval: The study was approved by the Institutional Ethics Committee

\section{REFERENCES}

1. Vousden N, Cargill Z, Briley A, Tydeman G, Shennan $\mathrm{AH}$. Caesarean section at full dilatation: incidence, impact and current management. The Obstetrician Gynaecologist. 2014 Jul 1;16(3):199-205.

2. Unterscheider J, McMenamin M, Cullinane F. Rising rates of caesarean deliveries at full cervical dilatation: a concerning trend. European J Obstet Gynecol Repro Biol. 2011 Aug 1;157(2):141-4.

3. Thomas J, Paranjothy S. The national sentinel caesarean section audit report. National Sentinel Caesarean Section Audit Report. 2001.

4. McKelvey A, Ashe R, McKenna D, Roberts R. Caesarean section in the second stage of labour: a retrospective review of obstetric setting and morbidity. J Obstet Gynaecol. 2010 Apr 1;30(3):264-7.

5. Loudon JA, Groom KM, Hinkson L, Harrington D, Paterson-Brown S. Changing trends in operative delivery performed at full dilatation over a 10-year period. J Obstet Gynaecol. 2010 May 1;30(4):370-5.

6. Govender V, Panday M, Moodley J. Second stage caesarean section at a tertiary hospital in South Africa. J Maternal-Fetal Neon Medi. 2010 Oct 1;23(10):1151-5.

7. Sung JF, Daniels KI, Brodzinsky L, El-Sayed YY, Caughey AB, Lyell DJ. Cesarean delivery outcomes after a prolonged second stage of labor. American J Obstet Gynecol. 2007 Sep 1;197(3):306-e1.

8. Alexander JM, Leveno KJ, Rouse DJ, Landon MB, Gilbert S, Spong CY, et al. Comparison of maternal and infant outcomes from primary cesarean delivery during the second compared with first stage of labor. Obstet Gynecol. 2007 Apr 1;109(4):917-21.

9. Selo-Ojeme D, Sathiyathasan S, Fayyaz M. Caesarean delivery at full cervical dilatation versus caesarean delivery in the first stage of labour: comparison of maternal and perinatal morbidity. Archives Gynecol Obstet. 2008 Sep 1;278(3):245-9.

10. Murphy DJ, Liebling RE, Verity L, Swingler R, Patel R. Early maternal and neonatal morbidity associated with operative delivery in second stage of labour: a cohort study. The Lancet. 2001 Oct 13;358(9289):12037.

11. Davis G, Fleming T, Ford K, Mouawad MR, Ludlow J. Caesarean section at full cervical dilatation. Austr New Zealand J Obstet Gynaecol. 2015 Dec;55(6):565-71.

12. Baloch S, Khaskheli M. Frequency of Second stage Intervention and its outcome in relations with instrumental vaginal delivery versus cesarean section. J Ayub Med Coll Abbottabad. 2008;20(1):87-90.

Cite this article as: Goswami KD, Parmar MM,

Kunjadiya AN. Study of fetomaternal outcome in second stage caesarean section. Int J Reprod Contracept Obstet Gynecol 2019;8:2169-71. 